\title{
OVER EXPRESSION OF VOLTAGE DEPENDENT ANION CHANNEL 2 (VDAC2) IN MUSCLES OF ELECTRICALLY STUNNED CHICKENS
}

\author{
NORShaHIdA AbU SAMAH ${ }^{1}$, AZURA AMID ${ }^{1,2}$ AND FARIDAH YuSOF ${ }^{1}$ \\ ${ }^{\text {I} B i o p r o c e s s ~ a n d ~ M o l e c u l a r ~ E n g i n e e r i n g ~ R e s e a r c h ~ U n i t, ~}$ \\ Department of Biotechnology Engineering, \\ ${ }^{2}$ International Institute for Halal Research and Training (INHART), \\ International Islamic University Malaysia, \\ P.O. Box 10, 50728 Kuala Lumpur, Malaysia. \\ azuraamid@iium.edu.my
}

\begin{abstract}
Water bath stunning is a common practice in commercial slaughterhouses. Such treatment is economic and in line with animal welfare practice. However, the conditions applied for the stunning process may vary from a slaughterhouse to another slaughterhouse. Such a loose regulation on the stunning procedure has opened up doors for food adulteration such as over dose stunning. In this study, a simple and reliable approach using proteomics have been developed to study the effect of different currents and voltages in stunning on the protein expression of the chickens. Protein profiles of the chickens were constructed in order to detect any differences in protein expression and modifications. The different voltage studied were $10 \mathrm{~V}, 40 \mathrm{~V}$ and $70 \mathrm{~V}$ while the values for current studied were $0.25 \mathrm{~A}, 0.5 \mathrm{~A}$, and $0.75 \mathrm{~A}$. After the proteomics analyses using 2D Platinum ImageMaster 6.0 and Matrix-assisted laser desorption ionization- time of flight (MALDI TOF) spectrometry identification, Voltage dependent anion channel 2 (VDAC2) was identified to be over expressed in the muscle sample of over stunned chicken. The over expression of VDAC2 was confirmed at the transcriptional level of RNA expression. Real Time PCR showed that all over stunned samples contained higher mRNA expression level for VDAC2 genes. The mRNA level of VDAC2 was upregulated by 59.87 fold change when normalized with housekeeping gene. In conclusion, VDAC2 could serve as potential biomarkers for identification of electrically stimulated chickens. The existence of these biomarkers will help to monitor the slaughtering and stunning process in the future. It will revolutionize the food authentication field and give a new breathe to the meat industry.
\end{abstract}

ABSTRAK: Kaedah "waterbath stunning" merupakan amalan biasa di pusat-pusat penyembelihan. Kaedah ini adalah ekonomik dan selari dengan amalan kebajikan haiwan. Walaubagaimanapun, syarat-syarat yang digunakan untuk proses kejutan tersebut mungkin berbeza antara sebuah pusat sembelihan dengan pusat sembelihan yang lain. Sebarang peraturan yang longgar semasa proses kejutan tersebut membuka ruang kepada adulterasi makanan seperti lebihan dos kejutan elektrik. Dalam kajian ini, satu pendekatan yang mudah dan boleh dipercayai menggunakan proteomik telah dibangunkan untuk mengkaji kesan arus dan voltan yang berbeza dalam proses kejutan elektrik terhadap ekspresi protin di dalam ayam. Profil protein ayam telah dibuat untuk mengesan sebarang perbezaan terhadap ekspresi dan modifikasi protin. Nilai voltan berbeza yang dikaji ialah $10 \mathrm{~V}, 40 \mathrm{~V}$ dan $70 \mathrm{~V}$ manakala nilai arus yang dikaji $0.25 \mathrm{~A}$, $0.5 \mathrm{~A}$, dan $0.75 \mathrm{~A}$. Selepas analisis proteomik menggunakan Platinum 2D ImageMaster 6.0 dan Matrix-Assisted Laser Desorption Ionization-Time of Flight (MALDI TOF) Spectrometry Identification, Voltage Dependent Anion Channel 2 (VDAC2) dikenal pasti terlebih ekspres di dalam sampel otot ayam yang terlebih dos kejutan elektrik. 
Lebihan ekspresi VDAC2 disahkan di peringkat transkripsi ekspresi RNA. Real Time PCR menunjukkan bahawa kesemua sampel yang terlebih dos kejutan mengandungi tahap ekspresi mRNA yang lebih tinggi di dalam gen VDAC2. Tahap mRNA VDAC2 dikawal oleh 59.87 perubahan kali ganda apabila dinormalkan dengan gen housekeeping. Kesimpulannya, VDAC2 boleh bertindak sebagai penanda biologi yang berpotensi untuk mengenal pasti ayam yang dirangsang elektrik. Kewujudan penanda biologi ini akan membantu memantau proses penyembelihan dan kejutan pada masa akan datang. Ia akan merevolusikan bidang pengesahan makanan dan memberi nafas baru kepada industri daging.

KEYWORDS: stunning; slaughtering; proteomics; voltage dependent anion channel 2; chicken muscle

\section{INTRODUCTION}

Stunning renders animals insensible during slaughtering procedures. Electrical stunning is accomplished by passing a sufficient amount of electrical current through the brain of birds for a given amount of time. Electrical stunning methods used in the past include electrified knives [1], electrified contact grids or plates and a V-shaped stunner but the most common is the water bath stunner. The electrical current passes the body from the head, which is in contact with the water in the bath, to the feet, which is in contact with a conveyor line. Water bath stunning is applied to relax neck muscles and contract wing muscles for easy fixation of the head for automatic killers, prevent excessive struggling and wing flapping during bleed out, facilitate rapid bleeding and relax or loosen feathers [2]. The efficiency of electrical stunning depends on the control of parameters such as voltage, amperage, current frequency and immersion time. Main adverse effects associated with high current or voltage stunning are wing hemorrhages, red skin conditions including red wing tips and pygostyles, poor plucking, broken bones and blood blemishes or blood coagulates in breast muscle [3].

Proteomics is a widely used tool in biomarker identification especially in disease development and cancer studies. A biomarker is a substance found in the blood, urine, cerebrospinal fluid, or tissues and is often detected in higher than normal amounts in samples with certain disease or condition [4] . For many diseases, such as cancer, protein function is altered in the context of key signaling pathways that regulate critical cellular functions including proliferation, apoptosis, differentiation, survival, immunity, metabolism, invasion, and metastasis [5]. Validation of a biomarker requires the analysis of thousands of samples to ensure that the potential biomarker is indeed related to a disease state and is not simply a function of the variability within the samples due to differences in diet, genetic background, lifestyle, and so on [6, 7]. Even though biomarker discovery has been mostly focused on prognosis and diagnosis of a disease, this approach is also suitable for other applications such as biomarkers for food adulteration. In addition to contaminated meats and incorrect labeling, such adulterations include over dose stunning during slaughtering process.

Voltage dependent anion channel (VDAC) has several isoforms which are VDAC-1, VDAC-2 and VDAC-3. This protein is a major component of the outer mitochondrial membrane, and highly conserved large conductance anion channel involved in fluxes of ions and metabolites across the outer mitochondrial membrane [8]. VDAC provides the main trans-membrane transport of ions, ATP and other metabolites through the outer mitochondrial membrane. VDAC shows both ion selectivity and voltage dependence [9]. In open state, anions are favored over cations, but the selectivity is relatively weak. Both 
Abu Samah et al.

positive and negative membrane potentials close VDAC. The voltage effect is symmetrical, and half maximal closure occurs at about $50 \mathrm{mV}$ [10]. VDAC closure very effectively blocks movement of organic anions, including respiratory substrates, creatine phosphate, ATP, ADP, and Pi [11]. VDAC closure also help to explain inhibition of metabolite movement during anoxia and the persistent suppression of mitochondrial function in cytopathic hypoxia during septic shock and multiple organ failure [12-14].

\section{MATERIAL AND METHODS}

\subsection{Experimental Design}

Female broiler chickens aged 35 days and weighing approximately $1.5 \mathrm{~kg}$ were collected from a farm in Kuang, Selangor, Malaysia, electrically stunned, and slaughtered. The two parameters studied for stunning were current and voltage with three levels each: $0.25 \mathrm{~A}, 0.5 \mathrm{~A}$ and $0.75 \mathrm{~A}$ for the current and $10 \mathrm{~V}, 40 \mathrm{~V}$ and $70 \mathrm{~V}$ for the voltage. The treatments for stunning were designed using a three-level full factorial design (Design Expert Software Version 6.0.8) and compared to the control, which was the non-stunned sample $(0 \mathrm{~A}, 0 \mathrm{~V})$. Two biological replicates were studied with three replicates of gels for each sample. A water stunner was designed to supply different sets of current and voltage. A glass aquarium was equipped with a copper plate sized $56.5 \mathrm{~cm} \times 28.5 \mathrm{~cm} \times 28.5 \mathrm{~cm}$. The positive terminal of the circuit was immersed in the copper plate of the aquarium while the negative terminal was attached to the shackle used to hang the chicken's leg. Each chicken was stunned for duration of 5 seconds.

\subsection{Sample Preparation}

Muscle was sampled from thigh and homogenized in 10 volumes of phosphate buffer (250 $\mathrm{mM}$ of $\mathrm{PO}_{4}{ }^{+}$buffer, $\mathrm{pH} 7.5,0.01 \%$ Triton X-100). The homogenate was centrifuged at $4^{\circ} \mathrm{C}, 10000 \times \mathrm{g}$ for 15 minutes and the supernatant was retained and stored at $-80^{\circ} \mathrm{C}$ until needed. The protein content of each sample was assayed using Bradford Assay [15].

\subsection{Two-Dimensional Gel Electrophoresis (2-D GE)}

Ten microgram $(10 \mu \mathrm{g})$ of sample was added to the sample buffer ( $7 \mathrm{M}$ urea, $2 \mathrm{M}$ thiourea, $4 \%$ CHAPS, $3 \mathrm{mg} / \mathrm{ml}$ DTT, $0.5 \%$ Pharmalyte) resulting in a total volume of $170 \mu \mathrm{l}$. After that, $170 \mu \mathrm{l}$ of rehydration buffer $(7 \mathrm{M}$ urea, $2 \mathrm{M}$ thiourea, $4 \%$ CHAPS, trace amount of bromophenol blue, $3 \mathrm{mg} / \mathrm{ml}$ DTT, $0.5 \%$ Pharmalyte) was added and the mixture was left at room temperature for 30 minutes. Isoelectric focusing was conducted on IPGphor 3 according to the manufacturer's protocol (GE Healthcare). The temperature was kept constant at $20^{\circ} \mathrm{C}$ and the current was maintained at $50 \mu \mathrm{A}$ per strip. After IEF, a second separation step (SDS-PAGE) was performed on a vertical setup of $12.5 \%$ polyacrylamide gel. The strips were reduced with $100 \mathrm{mg}$ of DTT dissolved in $10 \mathrm{ml}$ of equilibration buffer (6 M urea, $50 \mathrm{mM}$ Tris- $\mathrm{HCl}, 30 \%$ glycerol, $2 \% \mathrm{SDS}$ ) and alkylated with $250 \mathrm{mg}$ of iodoacetamide in equilibration buffer with a trace amount of bromophenol blue. The IPG strip was sealed in place using $0.5 \%$ agarose solution dissolved by heat in electrophoresis buffer (250 mM Tris, $1920 \mathrm{mM}$ glycine, $1 \%$ SDS). After electrophoresis, the gel was stained with silver nitrate solution for visualization. The gels were scanned by using ImageScanner III LabScan 6.0 software (GE Healthcare). The scanner was set at 300 dpi, transparent mode with green filter.

\subsection{Proteomic Analysis of ImageMaster Platinum 6.0}


Abu Samah et al.

Protein spots were detected and analyzed using ImageMaster 2D Platinum 6.0 software (GE Healthcare). After proteomics software analysis, the spots of interest were identified. The sample was run again on the same conditions and stained with Coomassie brilliant blue instead of silver staining as silver staining is incompatible with mass spectrometry analysis. After staining with Coomassie brilliant blue, the spot of interest were manually excised and subjected to MALDI-TOF mass spectrometry analysis. The excised spot from the gel was digested with trypsin and subjected to Zip Tip purification.

\subsection{MALDI TOF Mass Spectrometry Analysis}

After ZipTip treatment, the spot was analyzed by MALDI TOF/TOF Mass Spectrometer (Applied Biosystems). Both MS and MS/MS spectra were recorded in the combination mode. In MS spectrum, 1800 shots were accumulated and 4500 shots were accumulated for each MS/MS spectrum. Protein was identified from their accumulated MS and MS/MS spectra by manual searching using a locally implemented MASCOT server and compared to SwissProt and NCBI database.

\subsection{Validation of Proteomics Result by Real Time PCR}

In order to confirm the identified candidate protein through proteomics analysis, a validation was conducted on the transcriptional level of RNA. RNeasy Lipid Tissue Mini Kit (Qiagen) was used for the extraction of total RNA. After the extraction of total RNA, the complementary DNA was synthesized by using SuperScript III CellsDirect cDNA Synthesis System (Invitrogen). The single-stranded cDNA concentration was measured and stored at $-20^{\circ} \mathrm{C}$ for further PCR amplification. The complete sequence for the candidate gene was obtained from NCBI database. Primers of the potential biomarker as well as the housekeeping gene were designed using Primer3 free software (hhtp://Frodo.wi.mit.edu/primer3/). Real Time PCR was conducted using SYBR Green as the detection method with dissociation curve analysis. The results were analyzed using MxPro software (Stratagene). The SYBR green $\mathrm{Ct}$ values from triplicate experiments were calculated to find an average $\mathrm{Ct}$ value for each sample. These average values were then used to calculate the ratio using a formula from Pfaffl [16]. For each experiment, 18S rRNA gene was used as the reference gene, and the non-stunned chicken muscle cDNA was the control sample.

\section{RESULTS}

It was observed that in $0.75 \mathrm{~A}, 70 \mathrm{~V}$ stunned chicken (Fig. 1), protein 1 was over expressed and it was completely not detected in the $0 \mathrm{~A}, 0 \mathrm{~V}$ non stunned samples (Fig. 2). Therefore, protein 1 could be considered as protein where expression was influenced by the electrical treatment introduced during stunning process.

In Fig. 3, for instance, gel number 97584 is the reference gel for $0.75 \mathrm{~A}, 70 \mathrm{~V}$ stunned chicken and displayed on the $\mathrm{Y}$ axis while gel number 97567 which is plotted on the $\mathrm{X}$ axis represents the non-stunned chicken. The number of matched spot displayed when gel number 97584 is plotted against gel number 97567 is 214 with data correlation of 0.907 . A correlation near to 1 indicates that the two gels were highly correlated. Therefore, any new spot emerged from gel number 97584 is considered as a true biomarker. 


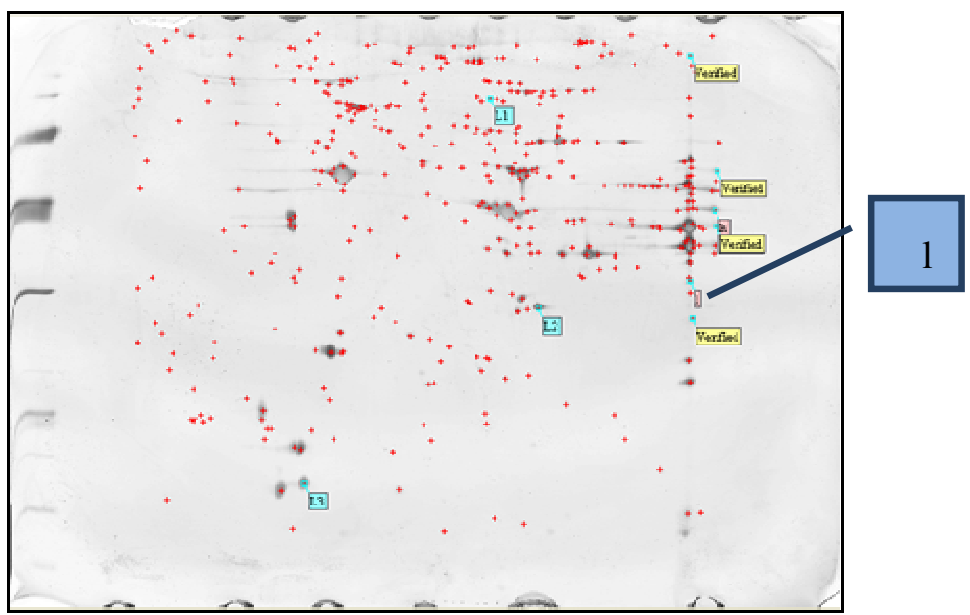

Fig. 1: Protein profile of $0.75 \mathrm{~A}, 70 \mathrm{~V}$ stunned chicken muscle.

The red crossed signs represent the detected protein spots. L1, L2 and L3 represent landmarks for gels alignment and matching. Protein 1 was identified as protein spot that was only detected in $0.75 \mathrm{~A}, 70 \mathrm{~V}$ stunned sample.

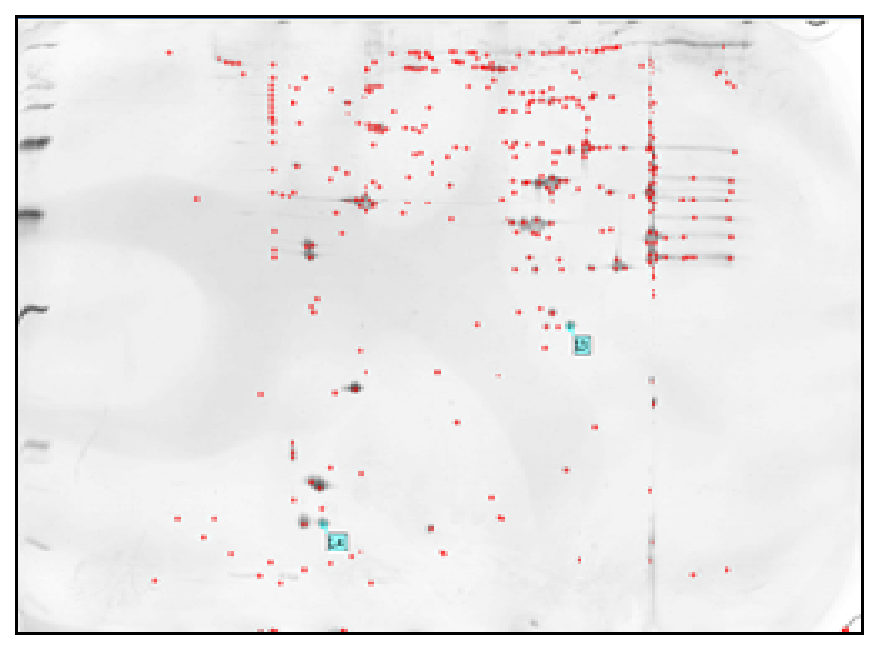

Fig. 2: Protein profile of $0 \mathrm{~A}, 0 \mathrm{~V}$ non stunned chicken muscle.

The red crossed signs represent the detected protein spots. L4 and L5 represent landmarks for gels alignment and matching.

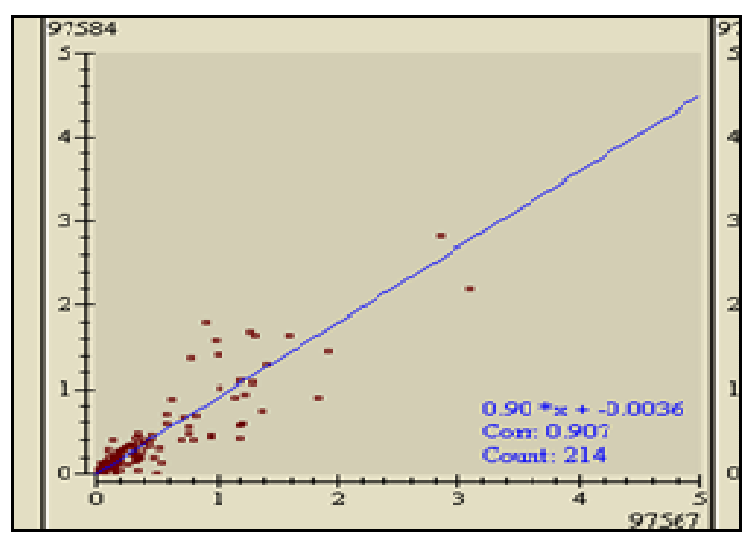

Fig. 3: Scatter plot for muscle sample.

The y axis represents $0.75 \mathrm{~A}, 70 \mathrm{~V}$ stunned sample while $\mathrm{x}$ axis represents $0 \mathrm{~A}, 0 \mathrm{~V}$ non stunned sample. Correlation near to 1 indicates that the two gels are highly correlated and free from staining variations. 
Figure 4 shows the Interaction graph of protein 1 . The graph was generated from the Design Expert software via 3-level full factorial design. It was shown that the protein intensity is increasing as the amount of voltage increase when the current was maintained at $0.75 \mathrm{~A}$. In contrast, the amount of protein intensity is decreasing as the amount of voltage increased when the current is set at low value $(0.25 \mathrm{~A})$. Therefore, the protein intensity was observed to be greatly influenced by the amount of current introduced during the stunning process. In Table 1, it was observed that current (B), interaction of voltage and current $(\mathrm{AB})$ and current $\mathrm{t}^{2}\left(\mathrm{~B}^{2}\right)$ had significant influence on the release of protein 1 with p-value of $0.0048,0.0336$ and 0.0219 respectively at $95 \%$ confidence level. There were only $0.48 \%, 3.36 \%$ and $2.19 \%$ that the variable terms F-value could occur due to noise. The lack of fit of 0.5610 is insignificant relative to pure error, and it is desirable because the model is expected to fit (Table 1).

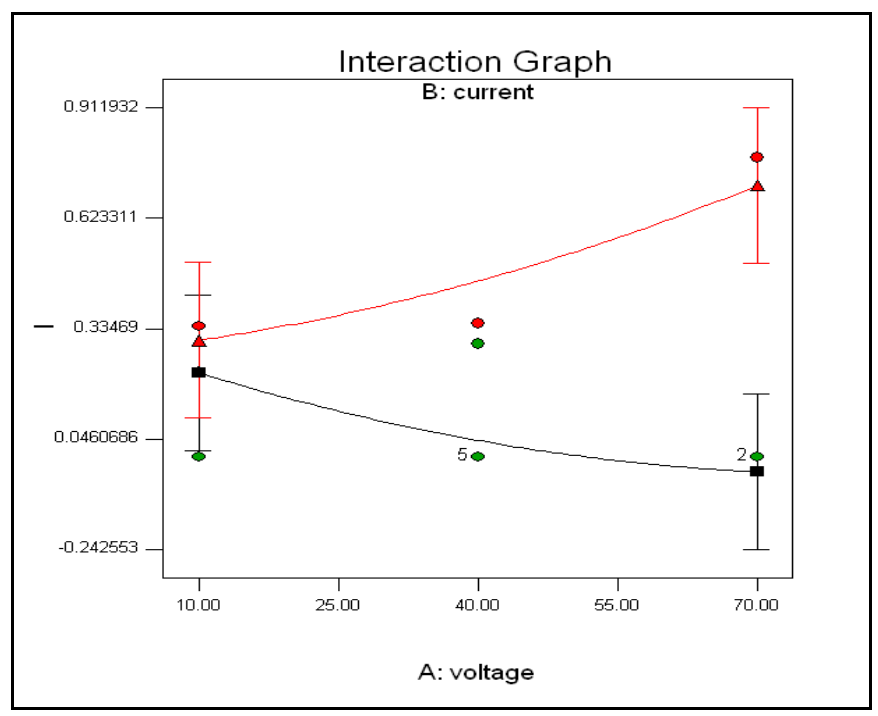

Fig. 4: Interaction graph for protein 1 intensity to the stunning parameters. The Interaction graph plots Protein Intensity versus Voltage (V). Red plot represents current at $0.75 \mathrm{~A}$ while black plot represents $0.25 \mathrm{~A}$.

Table 1: Analysis of variance for protein 1 intensity. A represents voltage while B represents current and $\mathrm{AB}$ represents the interaction between voltage and current.

\begin{tabular}{cccccccc}
\hline \multirow{2}{*}{ Protein } & Model & A & B & AB & $\mathbf{A}^{\mathbf{2}}$ & $\mathbf{B}^{\mathbf{2}}$ & $\begin{array}{c}\text { Lack of } \\
\text { Fit }\end{array}$ \\
\cline { 2 - 8 } & \multirow{2}{*}{0.0109} & 0.5000 & 0.0048 & 0.0336 & 0.5495 & 0.0219 & 0.5610 \\
\hline
\end{tabular}

After proteomics analysis, protein 1 was identified as Voltage dependent anion channel 2 (VDAC2) via MALDI TOF mass spectrometry (Table 2). After MALDI TOF identification, the expression levels were further confirmed at the transcriptional level by Real Time PCR. The VDAC2 gene has been up-regulated by 59.87 fold change in $0.75 \mathrm{~A}$, $70 \mathrm{~V}$ stunned sample compared to the $0 \mathrm{~A}, 0 \mathrm{~V}$ non stunned chicken muscle (Table 3). Gene up-regulation on the VDAC2 gene confirmed the findings from MALDI-TOF analysis, thus, suggesting the protein as promising biomarker in identification of electrically stimulated chicken meat. 
Table 2: Identification of protein 1 by MALDI-TOF spectrometry. Protein 1 was identified as Voltage dependent anion channel 2 (VDAC2).

\begin{tabular}{cccccccc}
\hline $\begin{array}{c}\text { Spot } \\
\text { ID }\end{array}$ & $\begin{array}{c}\text { Protein } \\
\text { name }\end{array}$ & $\begin{array}{c}\text { Accession } \\
\text { No }\end{array}$ & $\begin{array}{c}\text { Protein } \\
\text { Mw }\end{array}$ & $\begin{array}{c}\text { Protein } \\
\text { Score }\end{array}$ & $\begin{array}{c}\text { Protein } \\
\text { Score } \\
\text { C.I \% }\end{array}$ & $\begin{array}{c}\text { Total } \\
\text { Ion } \\
\text { Score }\end{array}$ & $\begin{array}{c}\text { Total Ion } \\
\text { Confirmed } \\
\text { C.I \% }\end{array}$ \\
\hline 1 & $\begin{array}{c}\text { Voltage- } \\
\text { dependent } \\
\text { Anion } \\
\text { Channel 2 }\end{array}$ & gil46048903 & 30293.3 & 460 & 100 & 394 & 100 \\
& & & & & & \\
\hline
\end{tabular}

Table 3: Real Time PCR validation of VDAC2 at transcriptional level.

\begin{tabular}{cccccccc}
\hline $\begin{array}{c}\text { Spot } \\
\text { ID }\end{array}$ & $\begin{array}{c}\text { Protein } \\
\text { Name }\end{array}$ & $\begin{array}{c}\text { Gene } \\
\text { name }\end{array}$ & $\begin{array}{c}\text { Vt } \\
\text { Value } \\
\text { Sample }\end{array}$ & $\begin{array}{c}\text { Ct } \\
\text { Value } \\
\text { Control }\end{array}$ & $\begin{array}{c}\text { Ct Value } \\
\text { Difference }\end{array}$ & $\begin{array}{c}\text { A } \\
\text { value }\end{array}$ & $\begin{array}{c}\text { Fold } \\
\text { Increment }\end{array}$ \\
\hline 1 & VDAC2 & VDAC2 & $\begin{array}{c}22.74 \pm \\
0.24\end{array}$ & $\begin{array}{c}24.18 \pm \\
0.24\end{array}$ & 1.44 & -3.237 & 59.87 \\
\hline
\end{tabular}

\section{DISCUSSION}

VDAC2 levels were up-regulated under iron deprivation in K562 (Human erythromyeloblastoid leukemia) cells by high resolution 2D electrophoresis and confirmed via Western blot analysis [17]. Iron deprivation is known to stimulate hypoxia and hypoxia induces membrane lipid peroxidation [18]. Stark studied that membrane lipid peroxidation results in the activation of VDAC-mediated transport [19]. VDAC is also useful in regulating some enzymes that involved in redox status control, such as, copper and zinc containing superoxide dismutase [20]. Cheng et al., studied that VDAC2 coevolved to regulate cell death and VDAC2 has a distinctive physiological role in vivo as a specific inhibitor of BAK (B-cell leukemia/lymphoma 2 homologous antagonist/killer)dependent mitochondrial apoptosis [21]. Chandra et al., suggested that an increase in VDAC2 complex formation in stimulated HCT116 (colonic epithelial) cells might be considered as a prosurvival mechanism activated by apoptotic stimuli [22].

In other studies conducted by Turko and Murad, [23] Mostyn et al., [24] and McCabe [25], VDAC has been associated with type 2 diabetes mellitus. In addition, VDAC accumulation has been associated with dystrophic neurites of $\beta$-amyloids plaques in Alzheimer's disease [26]. Yuqi et al., concluded that an increased expression of mitochondrial VDAC and subcellular co-localization of VDAC/Bax increases mitochondrial permeability and apoptosis [27]. The increased of VDAC expression highlight the potential importance of mitochondrial genes in the etiology of hypertension. VDAC seems to act as a brake on mitochondrial metabolism. In other instances, dynamic regulation of VDAC conductance by glucose-metabolizing enzymes may control insulin secretion in pancreatic beta cells and aerobic glycolysis in cancer cells. However, excessive VDAC closure may also promote apoptosis, cytopathic hypoxia, fatty liver disease and other pathophysiological changes. VDAC acts as a governator that establishes 
Abu Samah et al.

set points for global mitochondrial activity that change in response to cellular needs and metabolic stresses.

It was observed that direct current of $600 \mu \mathrm{A}$ and monophasic current of 2.5 to $3.0 \mathrm{~mA}$ with pulse duration of 300 microseconds and $100 \mathrm{~Hz}$ stimulate the expression of wound healing protein, vascular endothelial growth factor (VEGF) in male Sprague-Dawley rats [28]. On the seventh days after surgical incision, it was observed that the skin VEGF expression was significantly elevated in the direct current group. Electrical stimulation with $4 \mathrm{~mA}$ rectangular pulses of $0.5 \mathrm{~ms}$ duration at $2 \mathrm{~Hz}$ lasting for 1 hour would be a potential treatment for preventing atrophy of denervated skeletal muscles [29]. Although electrical stimulation alone is effective to prevent muscle atrophy, the combination of electrical stimulation and isometric contractions was observed to have further effect [30]. Electrical stimulation of cultured cartilage explants was discovered to result in significant increases in proteoglycan and collagen production and a highly significant upregulation of aggrecan and type II collagen mRNA expression [31]. These findings support the contention that delivery of a specific, defined electrical field to articular cartilage could result in matrix preservation and wound healing. Meanwhile, a delivery of high current and voltage will cause an over expression of hypoxia associated mitochondrial protein such as voltage-dependent anion channel 2 .

\section{CONCLUSION}

We found voltage-dependent anion channel 2 (VDAC2) to be elevated in the samples of muscles of chickens stunned at $0.75 \mathrm{~A}, 70 \mathrm{~V}$. This protein is completely absent in the samples from non-stunned $(0 \mathrm{~A}, 0 \mathrm{~V})$ chickens. When confirmed at the transcriptional level, the gene coding for VDAC2 exhibited up-regulation of 59.87 fold in samples from chickens stunned with $0.75 \mathrm{~A}, 70 \mathrm{~V}$. Therefore, VDAC2 could be potentially developed as a biomarker for identification of over stunned chicken in the market.

\section{ACKNOWLEDGEMENTS}

We would like to thank the MOHE of Malaysia for funding the research through research grant FRGS 02-07-43 and the Ministry of Science, Technology and Innovation (MOSTI) for providing an NSF scholarship for Norshahida Abu Samah throughout her MSc program.

\section{REFERENCES}

[1] H.J. Reynolds, "Recent developments in poultry processing", American Poultry Journal, vol. 74 (4), pp. 17-21, 1943.

[2] J.A. Dickens, and A.D. Shackelford, "Feather-releasing forces related to stunning of chickens, and its effect on the quality of the meat", Fleischwirtschaft, vol. 68, pp. 1416$1420,1988$.

[3] N.G Gregory, "From stunning and slaughter", In Processing of Poultry, Edited by G.C. Mead, London, Elsevier Sci Publishers Ltd, 1989.

[4] J.S. MacNeil, "Better biomarkers for the diagnostics labyrinth", Genome Technol, pp. 2433, 2004.

[5] K.R. Calvo, L.A. Liotta, and E.F. Petricoin, "Clinical proteomics: from biomarker discovery and cell signaling profiles to individualized personal therapy", Bioscience Reports, vol. 25, pp. 107-125, 2005. 
[6] S.P. Gygi, G.L. Corthals, Y. Zhang, Y. Rochon, and R. Aeberson, "Evaluation of twodimensional gel electrophoresis based proteome analysis technology", PNAS, vol. 97 (17), pp. 9390-9395, 2000.

[7] T. Rabilloud, "Detecting proteins: Separated by 2-D gel electrophoresis", Anal Chem, vol. 72 (1), pp. 48A-55A, 2000.

[8] M.A. Baker, D.J. Lane, J.D. Ly, V. De Pinto, and A. Lawen, "VDAC1 is a transplasma membrane NADH-ferricyanide reductase", J Biol Chem, vol. 279, pp. 4811-4819, 2004.

[9] V.A. Menzel, M.C. Cassara, R. Benz, V. De Pinto, A. Messina, V. Cunsolo, R. Saletti, K.D. Hinsch, and E. Hinsch, "Molecular and functional characterization of VDAC2 purified from mammal spermatozoa", Bioscience Reports, vol. 29, pp. 351-362, 2009.

[10] J.J. Lemasters, and E. Holmuhamedov, "Voltage-dependent anion channel (VDAC) as mitochondrial governator - thinking outside the box", Biochimica et Biophysica Acta, vol. 1762, pp. 181-190, 2006.

[11] T.K. Rostovtseva, A. Komarov, S.M. Bezrukov, and M. Colombini, "VDAC channels differentiate between natural metabolites and synthetic molecules", J Membr Biol, vol. 187, pp.147-156, 2002.

[12] E.D. Crouser, "Mitochondrial dysfunction in septic shock and multiple organ dysfunction syndrome", Mitochondrion, vol. 4, pp. 729-741, 2004.

[13] M.P. Fink, "Bench-to-bedside review: cytopathic hypoxia", Crit Care, vol. 6, pp. 491-499, 2002.

[14] M.P. Fink, "Research: advances in cell biology relevant to critical illness", Curr Opin Crit Care, vol. 10, pp. 279-291, 2004.

[15] M.M. Bradford, "A rapid and sensitive method for the quantification of microgram quantities of protein utilizing the principle of protein-dye binding", Anal Biochem, vol. 72, pp. 248-254, 1976.

[16] M.W. Pfaffl, "A new mathematical model for relative quantification in real-time PCR", Nucleic Acids Research, vol. 29 (9), pp. 2002-2007, 2001.

[17] K. Valis, J. Neubauerova, P. Man, P. Pompach, J. Vohradsky, and J. Kovar, "VDAC2 and aldolase A identified as membrane proteins of K562 cells with increased expression under iron deprivation", Mol Cell Biochem, vol. 311, pp. 225-231, 2008.

[18] C. Behn, O.F. Araneda, A.J. Llanos, G. Celedon, and G. Gonzalez, "Hypoxia-related lipid peroxidation: Evidences, implications and approaches", Respir Physiol Neurobiol, vol. 158, pp. 143-150, 2007.

[19] G. Stark, "Functional consequences of oxidative membrane damage", J Membr Biol, vol. 205, pp. 1-16, 2005.

[20] M. Budzinska, H. Galganska, M. Wojtkowska, O. Stobienia, and H. Kmita, "Effects of VDAC isoforms on CuZn-superoxide dismutase activity in the intermembrane space of Saccharomyces cerevisiae mitochondria", Biochem Biophys Res Commun, vol. 357, pp. 1065-1070, 2007.

[21] E.H.Y. Cheng, T.V. Sheiko, J.K. Fisher, W.J. Craigen, and S.J. Korsmeyer, "VDAC2 inhibits BAK activation and mitochondrial apoptosis", Science, vol. 301, pp. 513-517, 2003.

[22] D. Chandra, G. Choy, P.T. Daniel, and D.G. Tang, "Bax-dependent regulation of Bak by voltage-dependent anion channel 2", The Journal of Biological Chemistry, vol. 280 (19), pp. 19051-19061, 2005.

[23] I.V. Turko, and F. Murad, "Quantitative protein profiling in heart mitochondria from diabetic rats", J Biol Chem, vol. 278, pp. 35844-35849, 2003.

[24] A. Mostyn, S. Pearce, T. Stephenson, and M.E. Symonds, "Hormonal and nutritional regulation of adipose tissue mitochondrial development and function in the newborn". Exp Clin Endocrinol Diabetes, vol. 112, pp. 2-9, 2004.

[25] E.R. McCabe, "Microcompartmentation of energy metabolism at the outer mitochondrial membrane: role in diabetes mellitus and other diseases", J Bioenerg Biomembr, vol. 26, pp. 317-325, 1994.

[26] I. Ferrer, "Altered mitochondria, energy metabolism, voltage-dependent anion channel, and lipid rafts converge to exhaust neurons in Alzheimer's disease", J Bioenerg Biomembr, vol. 41, pp. 425-431, 2009. 
[27] L. Yuqi, G. Lei, L. Yang, L. Zongbin, X. Hua, W. Lin, C. Rui, L. Mohan, W. Yi, G. Minxin, and W. Shiwen, "Voltage-dependent anion channel (VDAC) is involved in apoptosis of cell lines carrying the mitochondrial DNA mutation", BMC Medical Genetics, vol. 10, p. 114, 2009.

[28] M.R. Asadi, G. Torkaman, and M. Hedayati, "Effect of sensory and motor electrical stimulation in vascular endothelial growth factor expression of muscle and skin in fullthickness wound". Journal of Rehabilitation Research \& Development, vol. 48 (3), pp. 195202, 2011.

[29] T. Arakawa, A. Katada, H. Shigyo, K. Kishibe, M. Adachi, S. Nonaka, and Y. Harabuchi, "Electrical stimulation prevents apoptosis in denervated skeletal muscle", NeuroRehabilitation, vol. 27 (2), pp. 147-154, 2010.

[30] N. Fujita, S. Murakami, T. Arakawa, A. Miki, H. Fujino, "The combined effect of electrical stimulation and resistance isometric contraction on muscle atrophy in rat tibialis anterior muscle", Bosn J Basic Med Sci, vol. 11 (2), pp. 74-79, 2011.

[31] C.T. Brighton, W. Wang, and C.C. Clark, "The effect of electrical fields on gene and protein expression in human osteoarthritic cartilage explants", J Bone Joint Surg Am, vol. 90 (4), pp. 833-848, 2008.

\section{NOMENCLATURE}

$2 \mathrm{D}$

MALDI TOF

PAGE
: Two dimensional

: Matrix assisted laser desorption ionization time of flight

: Polyacrylamide gel electrophoresis 